WSRC-TR-92-175

\title{
APPLICABILITY OF THE SLUDGE PROCESSING TECHNICAL STANDARD TO TYPE IV WASTE TANKS WITH HIGH FLUORIDE CONCENTRATION (U)
}

by P. E. Zapp

WSRC-TR--92-175

Westinghouse Savannah River Company

Savannah River Site

DE93 008799

Aiken, South Carolina 29808

Other Authors:

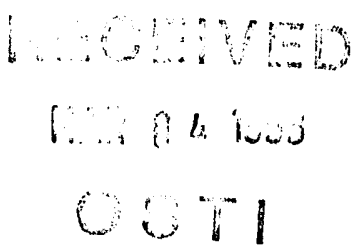

This paper was prepared in connection with work done under Contract No. DE-AC09-89SR18035 with the U. S. Department of Energy. By acceptance of this paper, the publisher and/or recipient acknowledges the U. S. Government's right to retain a nonexclusive, royalty-free license in and to any copyright covering this paper, along the right to reproduce and to authorize others to reproduce all or part of the copyrighted paper. 


\section{DISCLAIMER}

This report was prepared as an account of work sponsored by an agency of the United States Government. Neither the United States Government nor any agency thereof, nor any of their employees, makes any warranty, express or implied, or assumes any legal liability or responsibility for the accuracy, completeness, or usefulness of any information, apparatus, product, or process disclosed, or represents that its use would not infringe privately owned rights. Reference herein to any specific commercial product, process, or service by trade name, trademark, manufacturer, or otherwise does not necessarily constitute or imply its endorsement, recommendation, or favoring by the United States Government or any agency thereof. The views and opinions of authors expressed herein do not necessarily state or reflect those of the United States Government or any agency thereof.

This report has been reproduced directly from the best available copy.

Available to DOE and DOE contractors from the Office of Scientific and Technical Information, P. O. Box 62, Oak Ridge, TN 37831; prices available from (615) $576-8401$.

Available to the public from the National Technical Information Service, U. S. Department of Commerce, 5285 Port Royal Rd., Springfield, VA 22161. 
WESTINGHOUSE SAVANNAH RIVER COMPANY SAVANNAH RIVER LABORATORY

C.
B. L. Lewis, 703-H
G. K. Georgeton, 703-H
T. C. Hsu, 703-H
T. L. Capeletti, 773-41A
D. L. Fish, 773-A

\title{
385355
}

WSRC-TR.92-175

Keywords:

Pitting, corrosion, carbon steel.

Retention

period: permanent

D. T. Hobbs, 773-A

J. P. Howell, 773-41A

J. I. Mickalonis, 773-A

B. J. Wiersma, 773-A

SRL Records (4)

March 31, 1992

\section{MEMORANDUM}

TO: W. L. Tamosaitis, 773-A

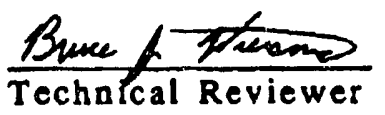

FROM: P. E. Zapp, 773-A P\&:Zepr

Approved:

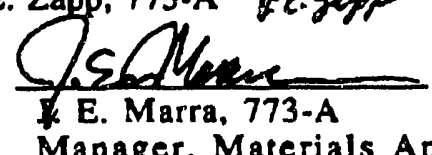

SRL

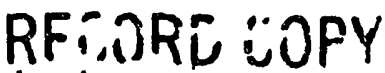

Manager, Materials Application ánd Corrosion Technology

\author{
Aoplicability of the Sludee Processine Technical Standard \\ 10 Type IV Waste Tanks with High Fluoride Conceneration (U)
}

\section{Summary}

Type IV waste tanks which contain ballast water (tanks 17, 18, 19, 20, and 24) have solution compositions that are generally within the database developed for corrosion protection of the sludge processing tanks. Therefore the technical standard covering tank chemistry limits during sludge processing is applicable to the Type IV tanks. However. Tank 20 contains levels of fluoride higher than those treated in the sludge processing database. To confirm the applicability of the sludge processing technical standard, cyclic potentiodynamic polarization scans for pitting susceptibility were run in a simulant of the Tank 20 contents. The nitrite inhibitor level specified by the standards did inhibit pitting corrosion in the simulant. Pitting was inhibited also at the same nitrite level but with 30 percent higher concentrations of chloride, fluoride, and sulfate. Thus the sludge processing technical standard has been shown to provide corrosion protection to type IV tanks containing ballast water.

\section{Discussien}

Among the eight type IV waste tanks, tanks 17 through 20 and tank 24 have been removed from active service; they contain ballast water and limited amounts of residual waste. In a previous report it was generally concluded that corrosion in these tanks can be inhibited by adhering to the limits in the technical standards established for highlevel radioactive waste slurries to be encountered in sludge processing (SP). ${ }^{1}$ These standards were developed through corrosion experiments on simulants of calculated average SP compositions. In these compositions, nitrate is the dominant corrosive ion; its concentration was shown to control the minimum effective level of nitrite required to inhibit corrosion. Only when the concentrations of other corrosive ions (chloride, fluoride, and sulfate) exceeded a critical ratio with respect to the nitrate concentration 
did these other ions becoming inhibitor controlling. The actual ratios of these other corrosive ions are well below or are expected to be well below the critical values in SP solutions. However, the concentrations of the fluoride and nitrate ions in $T$ ank 20 produce a ratio that does exceed values tested in the pitting corrosion database. This report describes the results of corrosion tests to confirm the applicability of the nitrite limits in the SP technical standard to dilute waste solutions with high fluoride concentration.

A sample was drawn from the liquid in Tank 20 in July, 1990. The nitrate concentration was deternined to be $0.0426 \mathrm{M}$. The free hydroxide concentration in tank 20 was $1.63 \mathrm{M}$, well above the $1.0 \mathrm{M}$ minimum for hydroxide. Tank 20 is thus well protected against pitting corrosion. The SP technical standard allows the inhibition of pitting corrosion with nitrite or hydroxide. ${ }^{2}$ The minimum nitrite concentration in a solution containing $0.0426 \mathrm{M}$ nitrate is $0.0710 \mathrm{M}$ at $40^{\circ} \mathrm{C}$. The actual tank 20 nitrite concentration was found to $0.368 \mathrm{M}$, well above the technical standard limit. However the fluoride concentration in tank 20 was 0.0659 , which yields a fluoride to nitrate ratio of 1.55 . While a critical fluoride to nitrate ratio has not been investigated in washed sludge solutions, the critical ratio in washed precipitate solutions is 0.3 , which does suggest potentially aggressive behavior from fluoride in the tank 20 solution. Therefore, experiments were conducted to determine the impact of the tank 20 fluoride concentration on the effectiveness of the nitrite concentration specified by the SP technical standard.

Cyclic polarization pitting scans were conducted in a simulant of the contents of Tank 20 using specimens of ASTM A537 Grade 1 (A537) carbon steel. Type IV tanks were constructed of ASTM A212 Grade B and ASTM A285 Grade B carbon steels. For corrosion testing purposes $A 537$ is an acceptable substitute for the two construction steels. The composition of the simulant is shown in Table $1 .^{3}$ The nitrite concentration in the simulants was either $0.368 \mathrm{M}$, the level found in tank 20 , or $0.0710 \mathrm{M}$, the technical standard value corresponding the tank 20 nitrate concentration. The tests were run at $40^{\circ} \mathrm{C}$. The $\mathrm{pH}$ of the test solutions was buffered at 10.63 , the calculated value of the $\mathrm{pH}$ of the tank aqueous phase at steady-state with absorbed atmospheric carbon dioxide. The scan parameters were those used previousl:" 4

The cyclic potentiodynamic polarization scans run at both nitrite levels showed no evidence of pitting corrosion. The scans revealed positive hysteresis between the forward scan current density and the reverse scan current density, indicating the absence of passive breakdown. The specimens were examined microscopically and were found free of pitting attack. To ensure that the technical standard nitrite limit $(0.071 \mathrm{M})$ was robust for this composition, an additional scan was run with the concentrations of the aggressive ions, sulfate, chloride, and fluoride, all increased by 30 percent. There was no evidence of pitting in this more aggressive solution.

\section{References}

1. P. E. Zapp and D. T. Hobbs, WSRC-TR-91-59, “Application of Technical Standard DPSTS241-5.03 to Type IV Waste Tanks Containing Ballast Water (U)," February 28, 1991.

2. Technical Standard, Waste Tank Farms, DPSTS-241-5.03.

3. D. T. Hobbs to P. E. Zapp, IWT-LWT-91-066, "Steady-State Hydroxide, Bicarbonate, and Carbonate Concentrations for Tank 20 Supernate," April 9, 1991.

4. P. E. Zapp, DPST-88-399, "Electrochemical Study of Corrosion Inhibition during Sludge Washing." March 14, 1988. 
Table 1

Composition of Tank 20 Test Solution

Species

Total Sodium Ion

Hydroxide

Bicarbonate

Carbonate

Nitrate

Nitrite

Aluminate

Sulfate

Fluoride

Chloride

Oxalate

Silicate

Chromate

Phosphate

Molybdate
Cencentration (Molar)

\subsection{8}

$4.25 \mathrm{E}-04$

0.438

0.932

4.26E-02

0.368 or $7.10 \mathrm{E}-02$

3.50E-02

7.36E-02

$6.59 \mathrm{E}-02$

2.80E-02

2.26E-02

$1.29 \mathrm{E}-03$

3.67E-04

2.97E-04

$3.06 \mathrm{E}-06$ 

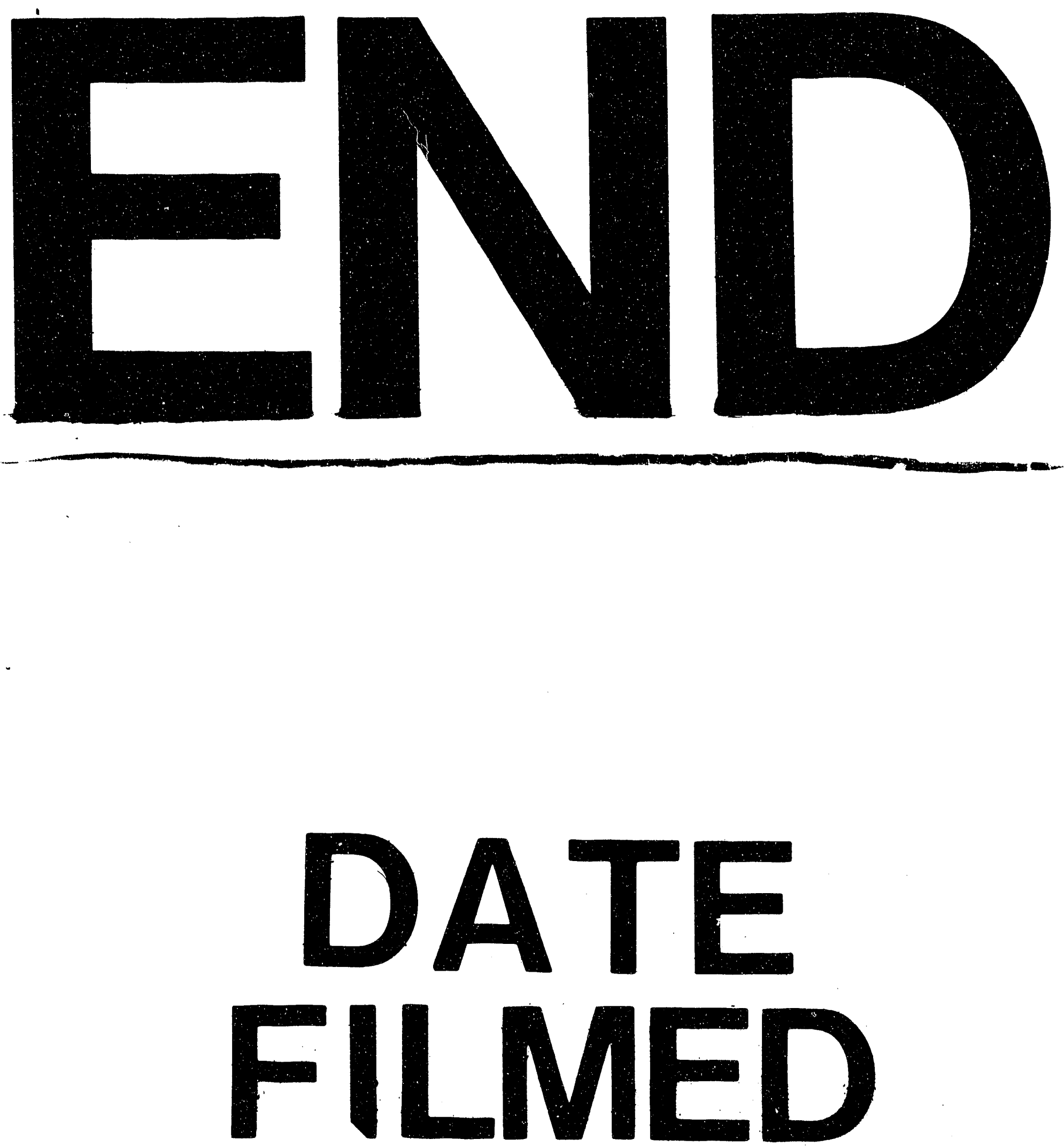

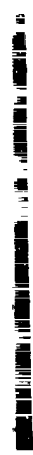

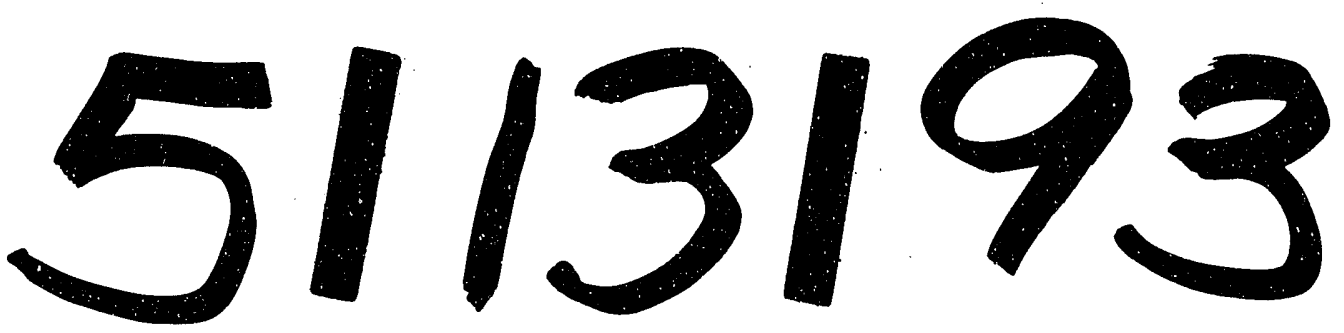


